\title{
Особливості художньої картини світу І. Сенченка (за повістю “Любов і Хрещатик")
}

\author{
Н. В. Ротова \\ Українська інженерно-педагогічна академія, Харків, Україна \\ Corresponding author. E-mail: rona19@ukr.net
}

Paper received 01.02.20; Accepted for publication 17.02.20.

\section{https://doi.org/10.31174/SEND-Ph2020-218VIII66-10}

\begin{abstract}
Анотація. Творчість Івана Сенченка залишається малодослідженою через те, що його твори не вкладалися в рамки соцреалізму. У статті досліджується роль міфопоетичних елементів та інтертекстуальності як чинників художньої світомоделі. Доведено, що інтертекстуальність реалізується в цитатах, алюзіях і конотаційних значеннях. Міфологема сім'ї - роду народу, яка традиційно відбиває духовний стан нації й має широке філософсько-узагальнююче значення, в повісті “Любов і Хрещатик” демонструє втрату культурних традицій нашого народу. Розгортання сюжету найчастіше конструюється автором із залученням мотиву ініціації, що дозволяє провести персонажі крізь різного роду випробування.
\end{abstract}

Ключові слова: світомодель, міфопоетика, міфологеми, інтертекстуальність, алюзія, конотачійне значення.

В історії української літератури є чимало письменників, творчість яких цілісно стала розглядатися й поціновуватися лише після отримання нашою країною незалежності. Серед них - Іван Сенченко. Традиційно його ім'я називалося серед тих, кого прийнято вважати “фундаторами” української радянської літератури; творчість письменника перебувала в колі уваги провідних українських критиків і літературознавців: К. Волинського [2], Л. Новиченка [7], І. Дзюби [5], В. Брюховецького [1]. Дослідники, аналізуючи стильову своєрідність творчості І.Сенченка, передусім підкреслювали спокійний плин оповіді, психологізм у творенні образу людини-трудівника, гармонійне поєднання ліричності з гумором і сатирою, проте представники вітчизняної критики не мали можливості говорити про ті твори, які не вкладалися в канони соціалістичного реалізму. Неможливість розглядати творчість письменника в усіх ii аспектах, обмежуючись лише дозволеними, стала причиною того, що півсотлітній його спадок грунтовно досліджувався небагатьма літературознавцями. Серед авторів найвагоміших праць про I. Сенченка слід назвати В. Брюховецького [1], М. Гнатюк [3, 4] та Л. Пономаренко [8].

Постійно слідкував за шляхом творчого зростання письменника видатний критик і літературознавець I. Кошелівець. Особливе місце в дослідженні творчості I. Сенченка посідає написана в 1976 році стаття "Поклонник шаленіючого сонця”, у якій І. Кошелівець не просто констатує наявність у І. Сенченка творів різного мистецького рівня, але й дає цьому явищу істинне пояснення: найкращі твори - це ті, “... у яких розкривалася душа і не треба було оглядатися на статут соцреалізму" [6, с. 14]. Проте, зауважує критик, прийшовши в літературу, письменник позбавлявся права не писати: "Писав і Сенченко, навіть досить багато: оповідань, повістей, романів, подорожних нарисів; я не буду ні обговорювати їх, ні навіть перераховувати, бо там немає справжнього Сенченка.” До творів, в яких є справжній Сенченко і які майже півтора десятиліття пролежали «у шухляді», належить і повість «Любов і Хрещатик», яка й стала предметом нашого дослідження, оскільки роль міфопоетичних елементів та інтертекстуальності як чинників художньої світомоделі практично не досліджувалася. Отже, зазначені лакуни у вивченні творчості I. Сенченка зумовлюють актуальність нашої роботи.

У повісті “Любов і Хрещатик” І.Сенченко намагається осмислити, як радянський неоміф про всюдисущого “ворога народу” став колективним підсвідомим, в який спосіб було створено відповідну світомодель, введено сонм нових богів, що, відповідно, вимагало скасування предковічної народної моралі й натомість введення в життя нових ритуалів, звичаїв та норм. Тобто, автор ставить перед собою завдання - розкрити наслідки політики, яка примусила український народ існувати у двох світоглядних площинах, коли “правда була неправда”'[11].

Про штучність радянської ідеології, про неправдивість уже за визначенням розмірковує Хосе Ортега-іГассет: "У випадку історичного камуфляжу одна на одну накладається дві реальності - глибинна, справжня, сутнісна й зовнішня, випадкова, поверхнева. Так, у Москви є оболонка європейської ідеї - марксизму, створеного в Європі стосовно європейських реалій і проблем. Під цією оболонкою - народ не просто етнічно інший... Перемога марксизму в Росії, де немає промисловості, була б чи не найбільшим протиріччям, 3 яким тільки зустрічався марксизм. Але цього протиріччя немає, тому й немає перемоги" [13, с. 125].

Отже, невипадково, що моделюючи світомодель суспільства, в якому неправда стала нормою існування й формою виживання, автор звертається до мотиву зради.

Відступництво, як спосіб пристосування, прослідковується передусім на образі Івана Івановича - людини від природи чесної й сором'язливої, яка, сприйнявши державну модель поведінки - “... не вб’єш ти тебе вб'ють!”, пердусім зраджує себе - стає відвертим негідником-”сигналістом”: “Він був здібний, чесний, наполегливий початківець, глибокої мирної вдачі. Коли б його не чіпали - і він вік не зачепив би нікого... Усі почали підозрювати одне одного у якихось страшних гріхах, викривати одне одного, писати одне на одного заяви і молотити, молотити, не розбираючи, куди впадуть ті удари" [12, с. 31].

Автору вдалося показати, як боляче чужа неприродна мораль увіходить у свідомість людини, стає іiі alterego, адже “... життя не терпить нещирості, бо, щось придумуючи, ми обов'язково це усвідомлюємо, бо вимисел ніколи не буває переконливий, і в глибині 
душі ми розуміємо його облуду. Інакше кажучи, неможливо до кінця обманутися, самого себе ловлячи на брехні [13, с. 502].

Так після першої “вдалої контратаки” Іван Іванович “... сидів смутний і все повторював: “Але ж це мерзота, підлість! Боже мій, як я міг так низько впасти! А найстрашніше те, що іншого шляху не бачу!" $[11$, с. 35] Натомість такий спосіб поведінки дає бажані наслідки: його починають боятися. "Здібний, працьовитий Іван Іванович, сам не помітивши того, перетворився на підступного і небезпечного інтригана" [11, с. 36] Як бачимо, радянський міф, ставши складовою особистості “Я” Івана Івановича, став керувати його поведінкою.

Поступово Іван Іванович звик до свого нового іміджу, і навіть зміни, які приніс XX партійний з'ізд, не позначилися на його свідомості, він продовжує керуватися набутими стереотипами й буває прикро вражений, коли вони не спрацьовують. Так, звикши ганьбити все нерадянське, він гостро виступає проти кібернетики як “буржуазної химери” й стає посміховиськом - “головним кібернетичним відьмаком".

Доказом парадоксальності радянської моралі, точніше, повної відмови від моралі загальнолюдської, може служити епізод, коли Іван Іванович, зустрівши колегу, намагається визначити, чи є той причетним до його падіння внаслідок “антикібернетичного” виступу: “Як зустріне його Сава Савич - 3 медом на вустах чи зробить вигляд, що не пізнав... Іван Іванович жадав зустрічі холодної, неуважної, буденної, бо тоді він напевне знав би, що у Сави Савича немає в думках солодкого меду... Сава Савич... глянув, пізнав і - зацвів... "Усе, - подумав Іван Іванович. - Кінець!" Остання надія обірвалася. Ножа в спину Івану Івановичу засадив Сава Савич" [11, с. 33]. Приязна посмішка дорого обійшлася Саві Савичу: на захисті його докторської дисертації Іван Іванович, не врахувавши змін у суспільній думці, влаштував брутальний скандал у дусі боротьби з ворогами народу - “А твій батько коня вкрав..." Отже, увійшовши в роль “борця $з$ проявами”, Іван Іванович навіть уявити не може, що винуватцем власного падіння $є$ він сам, проте, не вдаючись до довгих роздумів, він робить усе, щоб знищити колегу і не лише як ученого. Якщо його виступ можна спробувати пояснити й вибачити ідейними мотивами, то нічого не може виправдати відвертого злочину: у плані знищення Сави Савича важливе місце відводилося знищенню рецензії, підписуючи яку Кошовий “використав такий склад чорнила, яке начисто линяло на десятий день після того, як ним було щось написане" [12, с. 35]. Проте злодіяння було негайно викрито, бо Іван Іванович не відмовився від оплати за рецензію, і його підпис у відомості залишився в бухгалтерії. "Пасаж “А твій батько кобилу вкрав” не вистрелив, тобто вистрелив, але заряд влучив не в Саву Савича, а в самого Івана Івановича" [12, c. 43]. Така поведінка Івана Івановича $є$ вражаючою саме ігноруванням загальнолюдських апріорних норм поведінки, які за будь-яких умов не можуть порушуватися.

Набуті манери - зрадництво й підступність - не змогли не відбитися й на сімейних стосунках, ставши способом родинного життя: “Ніде правди діти, стави- вся Іван Іванович до своєї дружини не ідеально, і Анатоль, підрісши, не раз зустрічав батька $з$ чужими жінками в таких закапелках міських парків, куди випадково потрапити аж ніяк не можна" [12, с. 56]. В даному разі, ми вважаємо, спрацьовує загальнодержавна модель поведінки, намагання наслідувати спосіб життя представників вищих ешелонів влади, розпуста яких ні для кого не була таємницею. Таким чином, зрадивши друзів, дружину, Іван Іванович знищує самого себе. “Опуститися, пасти, принизитися - це й означає зректися себе, від такого, яким ти повинний був здійснитися. Існування при цьому не зникає, а стає" докірливою тінню, примарою, що вічно нагадує, яка низька твоя доля й якою несхожою вона повинна була стати. Таке життя - лише невдале самогубство" [13, с. 103].

Цілком логічним є те, що мотив скандалу, який на той час був нормою войовничої моралі й носив загальнодержавний характер, в повісті постає домінантним: скандальна стаття Івана Івановича про шкідливість “вигаданої за рубежем науки” кібернетики стала причиною його падіння як ученого, хоча саме ж таки політичні скандали сприяли його кар'єрі - “... звання доктора наук йому було присуджене в спосіб гоноріскаузе - без захисту дисертації, за дисертацію зарахували всі його палкі філіпіки супроти тих людей, яких тоді вважали ворогами народу і які тепер були посмертно реабілітовані” [11, с. 33].); ординарним явищем стали скандали в сім'ї Кошових, бо ніхто не хоче виявити ані найменшої толерантності й намагання зрозуміти іншу сторону; скандалом, як уже згадувалося, закінчується захист докторської дисертації Сави Савича, де опонентом виступає Іван Іванович; скандали відбуваються і в сім’ї Бабичів, де також не можуть порозумітися Калістрат Юхимович і Михайло; “одійшов від дочки” Сидір Карпович, визнавши свою поразку в намаганнях зрозуміти, що відбувається 3 дочкою, бо його рідна “...дитина стала немов чужа, незрозуміла, несла з собою аж відразу якусь.” Цілком логічним $\epsilon$ те, що в цій суцільній боротьбі не може не бути переможених, отже мотив помсти займає в повісті значне місце. Так саме віра у неминущість “вендети" тримає на світі Івана Івановича: "Відтоді Іван Іванович узяв за звичай щодня записувати подібні репліки на свою адресу; все це може колись стати в нагоді. I частенько уявляв. Світ знову нормалізувався, він, Іван Іванович, знову вискочив угору і - в якому ж сяйві, якому світлі!.. Отоді б він навчив цих голоцманків, як жити на світі!” [11, с. 10].

Войовничим борцям 3 антирадянськими привидами автор протиставляє професора Пташняка - справжнього Учителя, який чесно робить свою справу. Неабиякий талант і природна порядність уберігли його від шляху Івана Івановича й Сави Савича, проте наука, як нам видається, стає для нього “внутрішньою еміграцією”. "У голові цього професора завжди снувався рій думок, i, коли він підіймався на кафедру, не слухати його було неможливо. Студенти, крім того знали: Пташняк був постійним консультантом при різних міністерствах, главках, трестах..." Складається враження, що Пташняк живе у власному світі: в середині 60-х він вперше чує від Івана Опари про голод на Україні 1954 року. “Дивно 
звучали для нього слова: страшна засуха, чорна земля, приречені люди. Він про це ніколи не чув!.. Тоді він розв'язував проблеми, які потім здійснювалися деякими заводами. I цей п'ятдесят четвертий, як і попередній, як і наступні роки, пролетіли для нього, мов одна хвилина, у напруженій праці, він не розгинав спини день і ніч... Невже таке могло бути?" [12, с. 26]. 3 позицій сьогоднішнього дня реципієнт, звичайно, може звинуватити вченого у самоізоляції, адже нам відомі імена людей, які знаходили в собі сили для боротьби. Проте зі значною мірою впевненості ми стверджуємо, що, перебуваючи у чітко окресленому соціальному колі і не буваючи в селах, професор справді міг не знати про реальне становище в країні, адже саме про це постійно дбала радянська влада.

Визначальною рисою професора $є$ цільність, внутрішня правдивість. Значну роль у розкритті образу відіграють символічні просторові елементи, насамперед зображення його помешкання. Незважаючи на те, що він живе один, у нього є Дім, чого не можна сказати про зовні благополучну сім'ю Кошових. Речей у нього майже немає, після смерті коханої дружини він “роздав усе, що вважав за зайве сусідам... Проте його кабінет - це царство книжок: “Шафи... були новенькі чи наново пофарбовані - сліпучо сяяли. Це світло, ряди барвистих корінців книжок, зблиски шафового скла робили кабінет урочистим.” Як відомо, книги обов'язкова ознака дома, що передбачає не лише духовність, але й особливу атмосферу інтелектуального затишку. У Пташняка книги не лише елемент інтер'єру, свідченням цього є його диспути з Кошовиммолодшим, в яких кібернетик виявляє себе справжнім “ліриком”, обізнаним як з рідною, так і зі світовою художньою літературою. Письменнику вдається підкреслити виняткову інтелігентність професора, яку він виявляє під час бесід. Так, зрозумівши, що Анатоль не дуже обізнаний в царині літератури, хоча намагається це приховати, він просто читає йому вірші, ненав'язливо висловлює власні думки.

У повісті книги набувають виразного символічного значення: вони, як лакмусовий папірець, “проявляють” сутність людей. Так, Іван Іванович ставить за провину Саві Савичу “нездоровий інтерес до Вальтера Скотта, до Степана Руданського... Хто у нас став першим передплатником зібрання творів мракобіса Федора Достоєвського?.. У кого книжкові полиці вгинаються під вагою саг про красивих англійських Форсайтів, під вагою томів кумира сучасних стиляг Хемінгуея, беззубого німецького пацифіста Ремарка? Сави Савича! Усе нездорове, що з'являється в нашому житті, - предмет жадібного зацікавлення докторанта, бо хто йому може бути ближчим за Каутського, КнутаГамсуна і... Еттлі?!” [12, с. 43].

У повісті “Любов і Хрещатик”, де викривальний мовив $є$ домінуючим, широке використання алюзій, посилання, цитації та автоцитації спрямоване передусім для посилення емоційного впливу на реципієнта.

Звикши паплюжити все нерадянське, Іван Іванович, вирішив у своїй статті знищити “вигадану за рубежем науку" кібернетику як явище "наскрізь ідеалістичне”. Його не зупиняє власна некомпетентність, головна увага приділяється емоціям: кібірнетику він порівнює 3 хіромантією, “... основоположника нової науки... назвав ворожбитом; згадувалися відьомський шабаш на Брокені і навіть Вальпургієва ніч.” Іван Іванович помилився, і через деякий час використана ним лексика часів середньовіччя стала в пригоді його опонентам, спрацював принцип бумеранга: "На лекціях в університеті, у себе в коридорах Інституту... чув, як летіло йому інколи вслід: “Головний Хіромант! Переможець Кібернетики!.. На світло вибрався! А йому б сховатися в найтемнішу Вальпургієву ніч!" [11, с. 10 , 31].

До біблійної лексики звертається автор, намагаючись показати, яку прірву створила подвійна мораль між батьками й дітьми. Іван Іванович повертається 3 роботи 3 повному розпачі: в архіві знайдено його донос на Івана Пантелеймоновича, який нещодавно призначений директором інституту. Вдома Іван Іванович бачить, що його син за допомогою “кози” копіює чужі креслення. Це його обурює: “Та це ж Анатоль краде чужу працю!.. Та як же це ти посмів піти на такий злочин?..” Анатоль гримнув: “Без фарисейства тільки...” Конотація абсолютно прозора: батько бачить порошинку в оці сина і не помічає пенька у власному.

Прийнявши рішення зірвати Саві Савичу захист дисертації і відповідно до цього підготувавшися, Іван Іванович дуже здивований реакцією аудиторії: "Нi один у залі не підвівся, не закричав на адресу Сави Савича: “Крові хочемо! Розіп'яти його, розіп’яти!” Як бачимо, автор, намагаючись передати найвищий ступінь людської жорстокості, на яку очікує й розраховує Кошовий, вдається до цитування Євангелія - крик натовпу, що вимагає страти Ісуса. Подбавши про симпатичеські чорнила для знищення власного підпису, Іван Іванович не відмовився від гонорару за рецензію - свого роду тридцять срібників. Отже, маємо алюзію на зраду Іуди.

Суттєву роль у авторській світомоделі посідає “література в літературі": згадуються імена й художні тексти як вітчизняного, так і світового письменства: Бориса Гринченка, Томаса Манні, Бласко Ібаньеса, Єріх Марії Ремарка, Джека Лондона, Ернста Хемінгуея, Анатоля Франса, Хоми Аквіната,Вальтера Скотта, Степана Руданського тощо. Усі ці імена згадуються в ході розмов персонажів і наукових та псевдонаукових дискусій, що дозволяє автору схарактеризувати своїх героїв - Івана Іларіоновича Пташняка як високоінтелектуальну особистостість 3 широким колом інтересів - від кібернетики до класичної й сучасної поезії; Івана Івановича Кошового - як обмеженого пристосуванця, Анатоля - як людину, яка перебуває “в дорозі” до себе.

Висновки. Дослідивши міфопоетичну та інтертекстуальну площини авторської світомоделі в повісті “Любов і Хрещатик”, доходимо таких висновків:

1) міфологема сім’ї - роду - народу, яка традиційно відбиває духовний стан нації й має широке філософсько-узагальнююче значення, в повісті “Любов і Хрещатик” демонструє руйнування сім’і, деградацію моральних засад, втрату культурних традицій нашого народу;

2) виняткову роль у творенні художньої реальності відіграють інтертекстуальні зв'язки, що реалізуються в цитатах, алюзіях і конотаційних значеннях, які на- 
бувають особливої ваги при творенні підтекстового заперечення зовнішньої оповіді;

3) автор досить часто звертається до біблійних образів та сюжетів, у такий спосіб посилюючи сатирично-викривальне звучання оповіді: неодноразово письменник цитує Біблію, зображуючи падіння Івана Івановича Кошового - персонажа повісті “Любов і Хрещатик»;

4) надзвичайно широке коло імен українських та зарубіжних письменників, представників науки й культури, про яких згадується в повісті «Любов і Хрещатик», інтегрує авторську світомодель до культурного метатексту.

Усе викладене вище дає нам право говорити про повість «Любов і Хрещатик» I. Сенченка як цікаве явище в історії української літератури, яке передає бажання письменника бачити українську громаду такою, що зберігає вічні моральні цінності свого народу й водночас відчуває себе частиною Всесвіту.

\section{ЛІТЕРАТУРА}

1. Брюховецький В.С. Іван Сенченко: Літ.-крит. нарис. К.: Рад. письменник, 1981.-159 с.

2. Волинський К.П. Любов’ю зігріте серце//Сенченко І.Ю. Діамантовий берег: Повісті та оповідання. - К.: Веселка, 1981. - С. 3-10.

3. Гнатюк М.М. Над текстами Івана Сенченка. - К.: Наукова думка, 1989. - 109 с

4. Гнатюк М.М. Творческая история "Червоноградского цикла" Ивана Сенченко как выражение идейнохудожественной эволюции писателя. - Автореферат на соискание ученой степени канд. филол. наук. - К., 1985. $18 \mathrm{c}$.

5. Дзюба I.М. Задавнені болі, незраджені надії: (Про повість I. Сенченка “Любов і Хрещатик”)//Дніпро. - 1988. - № 2. - C. 61-62.

6. Кошелівець I. Поклонник шаленіючого сонця: Пам'яті Івана Сенченка (12.2.1901 - 9.11.1975)//Сучасність. 1976. - Ч. 2. - C. 8-17.
7. Новиченко Л. Предисловие к повести “Савка” И. Сенченко//Дружба народов. - 1980. - № 4. - С. 69.

8. Пономаренко Л.М. Художня еволюція Івана Сенченка. Автореферат на здобуття наук. ступеня канд. філол. наук. - K., 2001. - 19 c.

9. Ротова Н.В. Знайомий і незнайомий Іван Сенченко. Монографічне дослідження. - Харків, 20014. - 107c.

10. Ротова Н.В. Проза Івана Сенченка: проблеми міфопоетики й інтертекстуальності. - Автореферат на здобуття наук. ступеня канд. філол. наук. - Х., 2006

11. Сенченко І.Ю. Любов і Хрещатик//Дніпро. - 1988. - № 1. - C. 8-49.

12. Сенченко І.Ю. Любов і Хрещатик//Дніпро. - 1988. - № 2. - C. 6-62.

13. Хосе Ортега и Гассет. Идеи и верования//Хосе Ортега и Гассет. Избранные труды: Пер с исп./Сост., предисл. и общ ред. А.М. Руткевича. - М.: Изд-во “Весь мир”, 1997. - C. 404-419.

\section{REFERENCES}

1. Bryukhovets'kyy V.S. Ivan Senchenko: Lit.-kryt. narys. - K.: 7. Novychenko L. Predyslovye k povesty "Savka" Y. Rad. pys'mennyk, 1981.-159 s.

2. Volyns'kyy K.P. Lyubov"yu zihrite sertse//Senchenko I.YU. Diamantovyy bereh: Povisti ta opovidannya. - K.: Veselka, 1981. - S. 3-10.

3. Hnatyuk M.M. Nad tekstamy Ivana Senchenka. - K.: Naukova dumka, 1989. - $109 \mathrm{~s}$.

4. Hnatyuk M.M. Tvorcheskaya ystoryya "Chervonohradskoho tsykla" Yvana Senchenko kak vyrazhenye ydeynokhudozhestvennoy évolyutsyy pysatelya. - Avtoreferat na soyskanye uchenoy stepeny kand. fylol. nauk. - K., 1985. $18 \mathrm{~s}$.

5. Dzyuba I.M. Zadavneni boli, nezradzheni nadiyi: (Pro povist' I. Senchenka "Lyubov i Khreshchatyk")//Dnipro. - 1988. № 2. - S. 61-62.

6. Koshelivets' I. Poklonnyk shaleniyuchoho sontsya: Pam"yati Ivana Senchenka (12.2.1901 - 9.11.1975)//Suchasnist'. 1976. - CH. 2. - S. 8-17.

Senchenko//Druzhba narodov. - 1980. - № 4. - S. 69.

8. Ponomarenko L.M. Khudozhnya evolyutsiya Ivana Senchenka. - Avtoreferat na zdobuttya nauk. stupenya kand. filol. nauk. - K., 2001. - $19 \mathrm{~s}$.

9. Rotova N.V. Znayomyy i neznayomyy Ivan Senchenko. Monohrafichne doslidzhennya. - Kharkiv, 20014. - 107s.

10. Rotova N.V. Proza Ivana Senchenka: problemy mifopoetyky y intertekstual'nosti. - Avtoreferat na zdobuttya nauk. stupenya kand. filol. nauk. - KH., 2006

11. Senchenko I.YU. Lyubov i Khreshchatyk//Dnipro. - 1988. № 1. - S. 8-49.

12. Senchenko I.YU. Lyubov i Khreshchatyk//Dnipro. - 1988. № 2. - S. 6-62.

13. Khose Orteha y Hasset. Ydey y verovanyya//Khose Orteha y Hasset. Yzbrannye trudy: Per s ysp./Sost., predysl. y obshch red. A.M. Rutkevycha. - M.: Yzd-vo "Ves' myr", 1997. - S. 404-419.

\section{Features of the artistic picture of the world I. Senchenko (by the story "Love and Khreshchatyk")}

\section{N. V. Rotova}

Abstract. Ivan Senchenko's creativity remains poorly researched because his works did not fit into the realms of social realism. The role of mythopoetic elements and intertextuality as factors of the artistic world model is investigated in the article. It is proved that intertextuality is realized in quotations, allusions and connotative meanings. The mythology of the family - the kind - of the people, which traditionally reflects the spiritual state of the nation and has a broad philosophical and generic significance, in the story "Love and Khreschatyk" demonstrates the loss of cultural traditions of our people. The plot unfolding is most often constructed by the author, with the motive of initiation, which allows the characters to go through all kinds of trials.

Keywords: world model, mythopoetics, mythologists, intertextuality, allusion, connotational meaning. 